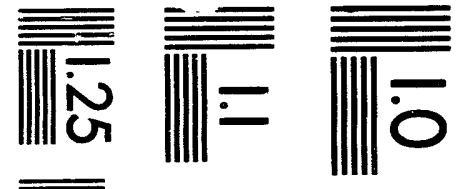

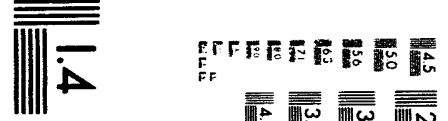

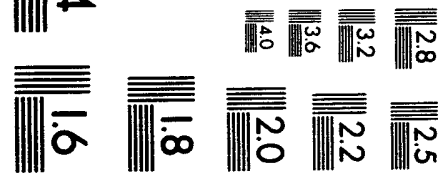



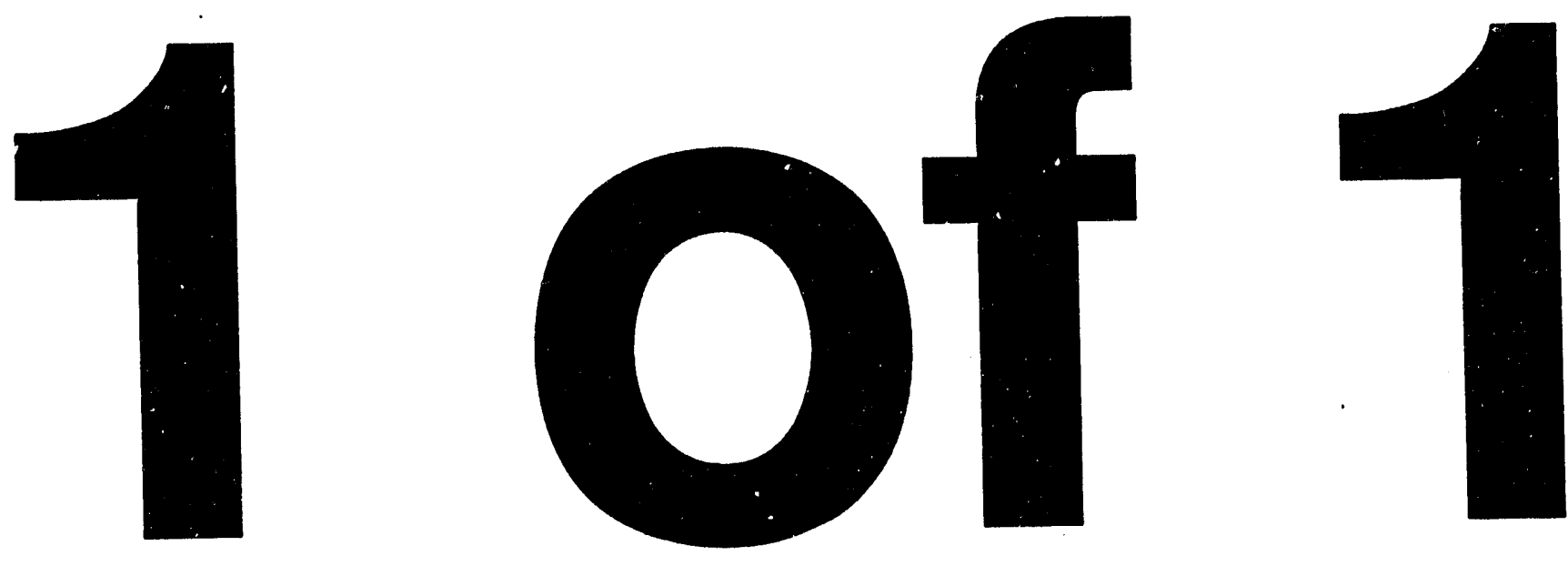
PROJECTS AT THE COMPONENT

\section{DEVELOPMENT AND INTEGRATION}

FACILITY

Quarterly Technical Progress Report

April 1 - June 30, 1993

Prepared by

MSE, Inc.

P.O. Box 3767

Butte, Montana 59702

\section{Prepared for}

U.S. Department of Energy

Under Contract DE-AC22-88ID12735

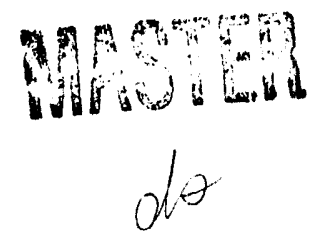




\section{ABSTRACT}

This quarterly technical progress report presents progress on the projects at the Component

Development and Integration Facility (CDIF) during the third quarter of FY93. The CDIF is a major U.S. Department of Energy test facility in Butte, Montana, operated by MSE, Inc. Projects in progress include:

- MHD Proof-of-Concept Project;

- Mine Waste Technology Pilot Program;

- Plasma Projects;

- Resource Recovery Project;

- Sodium Sulfide/Ferrous Sulfate Project;

- Soil Washing Project; and

- Spray Casting Project. 


\section{CONTENTS}

Page

MHD PROOF-OF CONCEPT PROJECT $\ldots \ldots \ldots \ldots \ldots \ldots$

MINE WASTE TECHNOLOGY PILOT PROGRAM $\ldots \ldots \ldots \ldots \ldots \ldots \ldots$

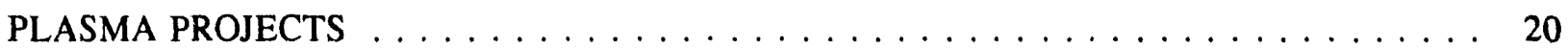

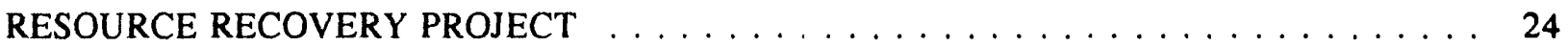

SODIUM SULFIDE/FERROUS SULFATE PROJECT $\ldots \ldots \ldots \ldots \ldots \ldots$

SOIL WASHING PROJECT $\ldots \ldots \ldots \ldots \ldots \ldots \ldots \ldots \ldots \ldots$

SPRAY CASTING PROJECT $\ldots \ldots \ldots \ldots \ldots \ldots \ldots \ldots \ldots \ldots \ldots$ 


\section{MHD PROOF-OF CONCEPT PROJECT}

Within the national magnetohydrodynamic (MHD) program, MSE personnel are responsible for performing integration testing of vendor-supplied MHD power train components at the Component Development and Integration Facility (CDIF) to support the proof-of-concept (POC) system demonstration goal leading to the commercialization of MHD.

\section{Testing Accomplishments}

MHD testing continued in April with initiation of the POC test series during the last week of a 2week test window (the previous week marked the end of the design verification test series). Testing was then shut down for a week, after which another 2-week test window was completed. This last test window was followed by a 3-week shutdown.

In April, 128 hours 36 minutes of thermal testing and 109 hours 57 minutes of power generation were accomplished, and a duration record for continuous time at design power operation (14 hours 54 minutes) was established during test 93-POC-8. Also, the most test hours accomplished during a week at the CDIF were achieved the week of April 12-16, with 54 hours 10 minutes thermal and 48 hours 46 minutes power generation being achieved.

The MHD POC test series continued in May. The beginning of the month coincided with the shutdown phase of the testing-shutdown cycle, which was followed by a 2 -week test period. The test period ended one day early when a burn-through was experienced on a channel side wall. Testing was discontinued for the remainder of the week, and the test train was dismantled to facilitate channel repair.

During May, 54 hours 58 minutes of thermal testing and 47 hours 22 minutes of power generation were accomplished.

The shutdown of the MHD POC test series continued in June, and channel and diffuser repair continued at the Textron Defense Systems facility. Delivery of the channel and diffuser to the CDIF is anticipated for July 9, and testing is scheduled to restart on July 20.

Table 1 is a summary of MHD tests run during the quarter.

\section{Operations Accomplishments}

Successful operation of the CDIF during the month of April allowed for many MHD testing records to be achieved. In support of that testing, a major effort was accomplished to supply and maintain sufficient quantities of consummables. Listed below are the amounts of consummables used.

- 900 tons of coal;

- 129 tons of seed;

- 1,542 tons of oxygen; 
TABLE 1 - MHD TESTS

\begin{tabular}{|c|c|c|c|c|c|c|c|}
\hline DATE & $\begin{array}{c}\text { TEST } \\
\text { NUMBER }\end{array}$ & TEST OBJECTIVES & $\begin{array}{c}\text { COAL } \\
\text { BURN } \\
\text { TIME } \\
\text { (hr:min) }\end{array}$ & $\begin{array}{l}\text { ENERGY } \\
\text { GENERATED } \\
\text { (MW hr) }\end{array}$ & $\begin{array}{l}\text { PEAK } \\
\text { POWER } \\
\text { (MW.) }\end{array}$ & $\begin{array}{l}\text { POWER } \\
\text { RUN TIME } \\
\text { (hr:min) }\end{array}$ & COMMENTS \\
\hline $3.29 / 3 \cap .93$ & 93.POC-1 & $\begin{array}{l}11 \text { Operate test train at duration operating conditions for } \\
\text { a } 24 \text { - hour period. } \\
\text { 21 Verify MHD generator output at reference oper ating } \\
\text { conditions. }\end{array}$ & $17: 20$ & 13.48 & 1.34 & $14: 17$ & 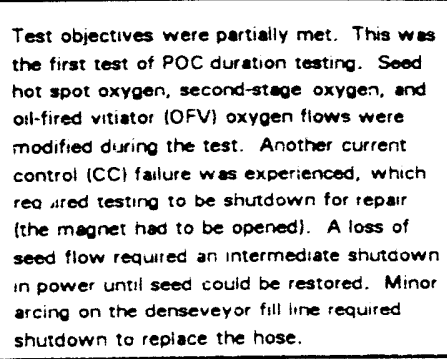 \\
\hline 3.31 .93 & 93-POC-2 & 11 Same as $93-\mathrm{POC}-1$ & $1: 21$ & 0.12 & 0.07 & $0: 28$ & 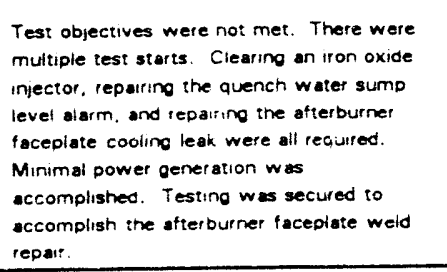 \\
\hline $4-9.83$ & $93-P O C-3$ & 11 Same as 93.POC-1. & 4:18 & 2.60 & 1.37 & 2:37 & 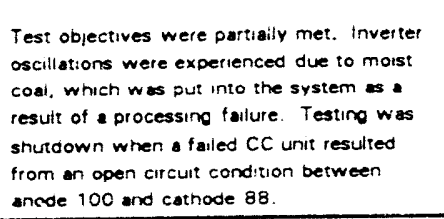 \\
\hline $4 \cdot 1 / 2 \cdot 93$ & 93-POC-4 & 11 Same as 93-POC-1. & $16: 28$ & 14.14 & $12^{n}$ & $14: 09$ & 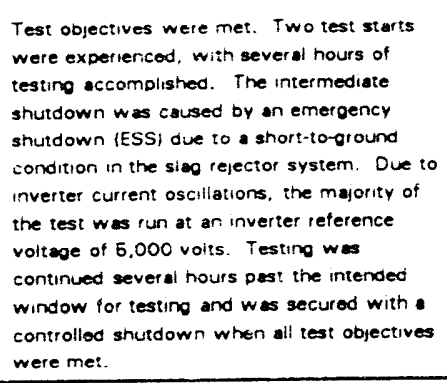 \\
\hline
\end{tabular}


TABLE 1 - MHD TESTS

\begin{tabular}{|c|c|c|c|c|c|c|c|}
\hline DATE & $\begin{array}{c}\text { TEST } \\
\text { NUMBER }\end{array}$ & TEST OBJECTIVES & $\begin{array}{c}\text { COAL } \\
\text { BURN } \\
\text { TIME } \\
\text { (hr:min) } \\
\end{array}$ & $\begin{array}{l}\text { ENERGY } \\
\text { GENERATED } \\
\text { (MW hr) }\end{array}$ & $\begin{array}{l}\text { PEAK } \\
\text { POWER } \\
\text { (MW.) }\end{array}$ & $\begin{array}{l}\text { POWER } \\
\text { RUN TIME } \\
\text { (hr:min) }\end{array}$ & COMMENTS \\
\hline $4-12 \cdot 93$ & 93-POC-6 & 11 Same es 93-POC-1. & 8:62 & 6.17 & 1.29 & $6: 18$ & 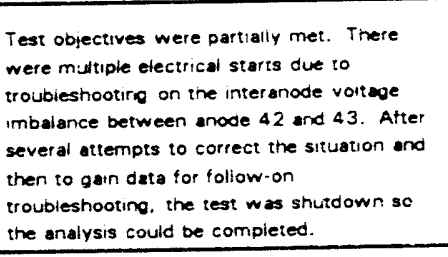 \\
\hline $4-13-93$ & 93-POC-6 & $1)$ Same as 93-POC-1. & 13:02 & 11.84 & 1.26 & $11: 31$ & 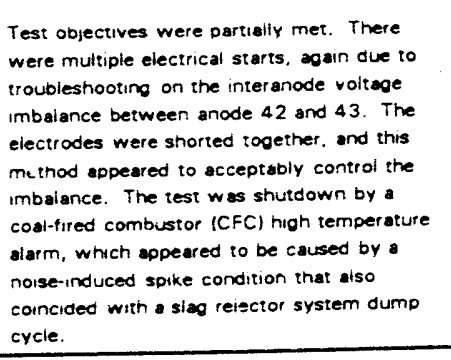 \\
\hline $4-14 / 15-93$ & 93-POC-7 & 11 Same as $93 \cdot \mathrm{POC}-1$. & $10: 00$ & 9.25 & 1.24 & $9: 16$ & $\begin{array}{l}\text { Test objectives were partially met. and } \\
\text { power testing was accomplished. Some } \\
\text { erratic inverter current was experienced. } \\
\text { Testing was shutdown when it appeared that } \\
\text { the siso tenk had become plugoed. The } \\
\text { post-test inspection revealed a siec dome } \\
\text { above the sleo grinder. }\end{array}$ \\
\hline $4-15 / 16-83$ & 93-POC-8 & 11 Same as 93-POC-1. & $22: 16$ & 23.14 & 1.31 & $21: 41$ & 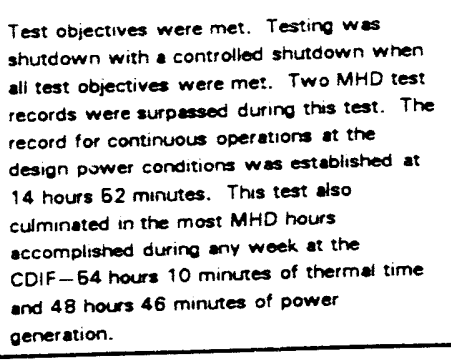 \\
\hline
\end{tabular}


TABLE 1 - MHD TESTS

\begin{tabular}{|c|c|c|c|c|c|c|c|}
\hline DATE & $\begin{array}{l}\text { TEST } \\
\text { NUMBER }\end{array}$ & TEST OBJECTIVES & $\begin{array}{c}\text { COAL } \\
\text { BURN } \\
\text { TIME } \\
\text { (hr:min) } \\
\end{array}$ & $\begin{array}{l}\text { ENERGY } \\
\text { GENERATED } \\
\text { (MW hr) }\end{array}$ & $\begin{array}{l}\text { PEAK } \\
\text { POWER } \\
\text { (MW.) }\end{array}$ & $\begin{array}{l}\text { POWER } \\
\text { RUN TIME } \\
\text { (hr:min) }\end{array}$ & COMMENTS \\
\hline $4-20-93$ & 93-POC-9 & 11 Same 93-POC-1. & $16: 44$ & 12.78 & 1.30 & $12: 28$ & 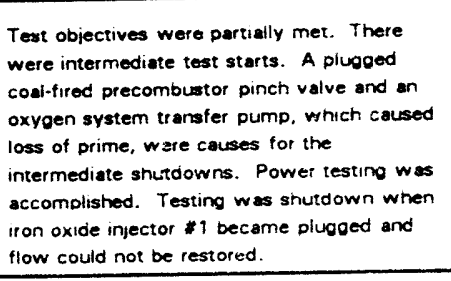 \\
\hline 4.22 .93 & 93-POC-10 & 1 Same as 93.POC-1. & 20:14 & 17.36 & 1.28 & $17: 12$ & 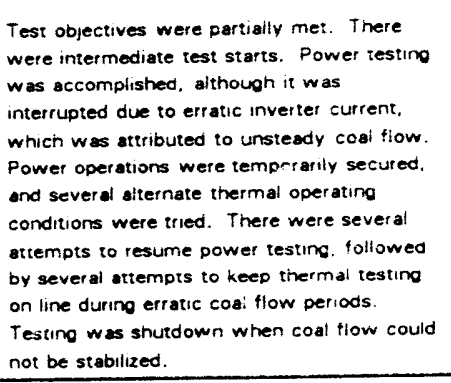 \\
\hline $6.17-53$ & $83-P O C-11$ & 1) Some as 93-POC-1. & $0: 17$ & NiA & N/A & MiA & $\begin{array}{l}\text { Test objectives were not met. Testino was } \\
\text { shutdown when the quench service water } \\
\text {; QSW) scrubber venturi was found } \\
\text { inoperable and unacceptabie particulate } \\
\text { emissions were being experiencer. Post-test } \\
\text { inspection revedied a fatled circuit toard in } \\
\text { the ventur: controlier. }\end{array}$ \\
\hline $5 \cdot 18 / 19-93$ & 83-POC-12 & 11 Same as $93-P O C-1$. & $2: 36$ & 0.02 & 0.31 & $0: 16$ & $\begin{array}{l}\text { Test objectives were not met. There were } \\
\text { several intermediate electricai starts. } \\
\text { Multiple open-circuit conditions were found } \\
\text { and repared. Testing was shutdown when. } \\
\text { transmitter fallure was experienced on the } \\
\text { scrubber water level instrumentation. }\end{array}$ \\
\hline 6-19-93 & 93-POC-13 & 11 Sarne as 93.POC-1. & $7: 27$ & 6.62 & 1.32 & $6: 46$ & $\begin{array}{l}\text { Test objectives were partially met. There } \\
\text { were multipie intermediate eiectrical starts. } \\
\text { Several iron oxide injection rates were } \\
\text { assessed. Due to a suspected slag tank } \\
\text { blockage, testino was shutdown. A post- } \\
\text { test inspection verified a slag bridge formed } \\
\text { above the slow grinder. }\end{array}$ \\
\hline
\end{tabular}


TABLE 1 - MHD TESTS

\begin{tabular}{|c|c|c|c|c|c|c|c|}
\hline DATE & $\begin{array}{c}\text { TEST } \\
\text { NUMBER }\end{array}$ & TEST OBJECTIVES & $\begin{array}{l}\text { COAL } \\
\text { BURN } \\
\text { TIME } \\
\text { (hr:min) } \\
\end{array}$ & $\begin{array}{l}\text { ENERGY } \\
\text { GENERATED } \\
\text { (MW hr) }\end{array}$ & $\begin{array}{l}\text { PEAK } \\
\text { POWER } \\
\text { (MW.) }\end{array}$ & $\begin{array}{l}\text { POWER } \\
\text { RUN TIME } \\
\text { (hr:min) }\end{array}$ & COMMENTS \\
\hline $5 \cdot 19 / 20 \cdot 93$ & 93-POC-14 & 11 Same as 93-POC-1. & $21: 06$ & 21.46 & 1.44 & $19: 41$ & 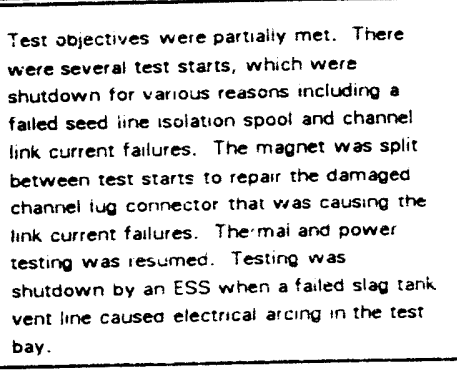 \\
\hline $5 \cdot 24: 25 \cdot 93$ & 93-POC-16 & " Same as $93-P O C-1$ & $6: 57$ & $6 / 40$ & 1.44 & $5: 44$ & $\begin{array}{l}\text { Test objectives were partially met, and } \\
\text { power testing was accomplished. An } \\
\text { intermediate test shutdown occurred due to } \\
\text { an inverter system malifunction that caused a } \\
\text { voltage-limiting device IVLDI trip. Testing } \\
\text { was remintated: it was shutdown with a } \\
\text { controlied shutdown due to a suspected stag } \\
\text { tank blockage. The plun was verfitied during } \\
\text { the post-test inspection. }\end{array}$ \\
\hline $5 \cdot 25: 26-93$ & $93 \cdot P O C \cdot 16$ & 11 Same as $93 \cdot P O C-1$ & $12: 48$ & 11.63 & 1.36 & $11: 38$ & $\begin{array}{l}\text { Test objectives were partially met. There } \\
\text { were muitiple thermal and power test starts. } \\
\text { Intermediate shutdowns were cassed by } \\
\text { voltage transients that induced CFC cooling } \\
\text { water out-of toleternce alarms and a coal } \\
\text { E +H meter tallure. A post-test inspection } \\
\text { also revealed a slag buldup in the slag tank. }\end{array}$ \\
\hline $5 \cdot 26-93$ & $93-\mathrm{POC}-17$ & 1 Same as $33-P O C-1$. & $0: 62$ & 0.65 & 1.36 & $0: 37$ & $\begin{array}{l}\text { Test objectives were not met. Minimal } \\
\text { power testing was accomplished betore an } \\
\text { inverter malfunction caused a VLD trip. } \\
\text { Diagnostic instrumentation was installed to } \\
\text { monitor inverter operation pefore testing } \\
\text { began. }\end{array}$ \\
\hline $5 \cdot 26-93$ & 93-POC-18 & 11 Same as 93-POC.1. & 2:56 & 2.90 & 1.38 & $2: 41$ & $\begin{array}{l}\text { Test objectives were partially met. There } \\
\text { was only one test start. Testing was } \\
\text { stutudown with a controlled shi. lown when } \\
\text { excessive magnet bore carbon monoxide } \\
\text { levels were observed. A post-test inspection } \\
\text { inc'uaed splitting the inagnet. A plasma teak } \\
\text { in the channel east lower sidewall was } \\
\text { discovered during the post-test inspection. } \\
\text { The leak required repair before testing } \\
\text { resumed. }\end{array}$ \\
\hline
\end{tabular}


- 1,185 tons of nitrogen;

- 23,700 gallons of ammonia;

- 17,775 gallons of premixed rust; and

- 11,665 gallons of fuel oil.

A modification was installed on the afterburner, which significantly reduced slag buildup.

During the quarter, the tasks listed below were completed by the Data Acquisition System (DAS) group.

- Software was installed to calculate global equivalence using dry oxygen measurements taken in the stack. This value will be used to compare against the equivalence calculated from the mass flow inputs.

- A program was written to calculate the total amount of slag removed during an MHD test, and this program was run for all 93 POC tests; an on-line version of this program will be installed for future MHD tests.

- A study was completed comparing coal flow from the Endress + Hauser $(E+H)$ meters with coal flow from the load cells.

- Data from tests 93-DVT-19 through 93-POC-10 was compared; the load cell data was 1.2 percent higher than the $\mathrm{E}+\mathrm{H}$ data.

- Software was installed to calculate slag removed during an on-line MHD test.

- The on-line coal correction program was modified to incorporate a new algorithm to correct the $\mathrm{E}+\mathrm{H}$ meters to the load cell calculated coal flow. This routine, which will make a correction once per coal cycle was run for the last three tests and resulted in improved coal flow.

- Four new calculated values were added to the on-line calculation program: 1) HALLICT calculates the number of times in the past hour that the hall current at frame 200 is less than 50 amps, 2) LOWICVS calculates the number of intercathode voltages below 10 volts, 3) MIDICVS calculates the number of intercathode voltages between 10 and 70 volts, and 4) HIGHICVS calculates the number of intercathode voltages above 70 volts.

- The continuous emissions monitoring system (CEMS) program was modified to perform a linear fit between values in the steam table, which should provide for a more accurate representation of the percent moisture in the stack.

- Software was installed on the DAS to calculate the weight of nitrogen used to replace coal in the coal injection vessel; this value was then used to correct the load cell coal flow calculation on the coal correction computer and on the DAS.

- The on-line display programs and post-test reports were modified to reflect the new channel configuration. 
- Thirty-five 500-hertz filters were fabricated and installed on selected channel electrical parameters in support of the current consolidator $(\mathrm{KC})$ checkouts.

- Bernouli format data files were generated for the most recent POC tests and sent to TRW.

During May, the evaporation pond liner was repaired; significant work on the combustor, as required and requested by TRW, was performed; and a more extensive checklist to minimize plant recovery problems after a shutdown period was developed and implemented. In addition, a way to use the evaporation ponds as makeup to the QSW used during MHD testing was developed, and significant savings in city water use resulted.

The channel and diffuser were removed and transported to the Textron Defense Systems facility for inspection and repair.

The changeover of ethylene glycol systems to propylene glycol was completed.

The Experimental Support Shop was dismantled and will be converted to support Resource Recovery testing.

Performance specification testing of the MHD CEMS was completed in April as scheduled. All emission measurements taken (both CEMS and manual) were well within permitted emission limitations; however, the relative accuracy of the data sets did not comply with Performance Test specifications.

In May, a summary of the Performance Specification Test results was submitted to the Montana State Air Quality Bureau as an Appendix to the Excess Emissions Report for the first quarter of 1993. The Air Quality Bureau suggested MSE retest because the relative accuracy of the test did not meet the specification of 40 Code of Federal Regulations 60; two-thirds of the test was successfully repeated on May 19 and 20, and the final third was aborted on May 27 along with MHD testing. Based on an agreement between MSE and the Air Quality Bureau to include the results of the retest, the delivery date of the final Performance Specification Test report was moved to June 9; the retest results meet the relative accuracy specification.

The final report of the Performance Specification Test conducted to evaluate the acceptability of data produced by the CEMS was completed and submitted to the State of Montana Air Quality Bureau as required by the CDIF Air Quality Permit. Successful completion of these tests demonstrates that CEMS data is valid for determining compliance with permitted emission limitations.

A draft modified air quality permit was received in April from the State of Montana Air Quality Bureau and was circulated for in-house review. On May 24, an application to revise draft permit 1528-03 was sent to the Air Quality Bureau. The purpose of this revision is to standardize plasma centrifugal furnace (PCF) particulate emission limitations and increase allowable annual operating hours from 500 to 1,000 , based on the Pit-9 off gas system modifications. These items were not incorporated into a common action as the Air Quality Bureau requested, and because the first one is a modification and the second is a revision, there is a significant dollar and documentation difference. A modified air quality permit was received from the Air Quality Bureau on May 28 and became effective on June 11; this modification includes deletion of the requirement for operating a sulfur dioxide CEMS on the MHD process: 
A Storm Water Pollution Prevention Plan was prepared and submitted to the Montana State Water Quality Bureau, as required by the National Pollutant Discharge Elimination System (storm water discharge) permit issued to the CDIF.

The permitting process for treating Berkeley Pit water at the CDIF is underway. This process involves DOE, State of Montana, and local agencies. DOE will review the proposed action for environmental acceptability (National Environmental Policy Act), the State of Montana will oversee the project under Superfund jurisdiction, and local agencies will regulate the discharge of processed water.

A revision application in increase the allowable annual operating hours of the PCF was sent to the State of Montana Air Quality Bureau.

\section{Plant Modifications and Upgrades}

\section{DOE Building Heating, Ventilation, and Air-Conditioning Upgrade and Sprinkler System Installation}

Categorical exclusions for the two projects were approved in April. Design activities were completed, and awarding of the subcontract for this installation is pending PETC approval. The proposed subcontractor has indicated they are ready to begin work once approval is received.

\section{Operations Building Sprinkler System}

Design work for the Operations Building sprinkler system installation project is scheduled to begin later this fiscal year. Installation is planned for next fiscal year but is dependent on available funding.

\section{Current Consolidators}

Westinghouse personnel completed all work on the KCs project, and Westinghouse successfully completed the acceptance test of the KCs the first week of May; the master KC computer was then moved to the central control room. MSE personnel completed installation and connection of the invertor buses in the KC power cabinets. Currently the buses are shorted inside the cabinet to support the first MHD test series without the KCs; the short will be removed for power testing with the KCs in August. The carbon dioxide fire extinguishing system was installed in both $\mathrm{KC}$ buildings.

\section{A Channel Look-Alike}

All work under this project was suspended in May at the direction of DOE. Channel fabrication was nearly complete, and High-Voltage Room modification design packages were approximately 80 percent complete; all design packages have been saved and stored for future use. 


\section{Plant Intercom}

The final design was completed on the plant intercom upgrade, and bids for this project were received. However, a major difference in the independent cost estimate and the bids prevented awarding of a subcontract. After reviewing the specifications, a second set of bids was requested with a change in scope and additional contract clarifications. Installation was rescheduled to begin in August or September, and the present plan is to complete this installation near the end of this fiscal year.

\section{Evaporation Ponds-Monitoring Wells}

The subcontractor installed the lysimeter wells that are adjacent to the coal and evaporation ponds, final documentation was completed, and the project was closed out. Monitoring of groundwater adjacent to the evaporation ponds began.

\section{Fuel Oil Tank Removal}

The fuel oil tank upgrade Title I design review was completed, and the Title II design was begun in April. The scope of this project was changed from removing the existing tank and replacing it with an above storage tank to removing the existing tank only. However, because the need for fuel oil for MHD testing still remains, the project schedule was revised. The design for removing the existing tank will be completed this fiscal year, and the physical work under this project will be scheduled after the need for fuel oil no longer exists. An environmental questionnaire and categorical exclusion for the fuel oil tank removal project was submitted to DOE-PETC for approval.

\section{Central Control Room Halon System}

The conceptual design review was completed as planned for the Central Control Room Halon system upgrade, and Title II design was completed in May. Initially, installation was scheduled for the JulyAugust shutdown; however, drawings for this project were not completed as planned. The bidding will occur during August, and installation will occur in September/October.

Below is a status of significant plant modifications made during this reporting period.

- A new afterburner endplate was fabricated and installed because the existing endplate had developed a number of uracks that produced leaks in the cooling passages. The new plate consists of improved fabrication techniques and cooling nozzles to provide for a more reliable system and seems to be working well.

- New injectors and a purging system were installed in the Ammonia System before POC MHD testing began in May. Spare nozzles were also fabricated, and to date, no problems have been noted.

- Failed pumps were replaced, and piping and lube oil temperature monitoring modifications were completed in the low-pressure couling system (LPCS) pump. At TRW's request, MSE continues to provide support on one pump that is still having high lube oil temperature problems. 
- The Nitrogen System vaporizer skid upgrade, which was originally scheduled to be done during the April shutdown, will not be done until June. Extensive work required for the LPCS pump upgrade prevented this work from being done.

- Checkout of the sequence of events system was completed.

- The work package for the TRW-requested modification to the VLD was completed, and installation is scheduled to be completed in June.

- Several recently completed modifications that improved the operation and reliability of the Oxygen System necessitated reinsu'ation of the piping. A subcontract for this installation was awarded, and work began. Installation wa scheduled to be completed by the end of June; however, it was delayed because of material delivery problems. All work should be completed in time to support MHD testing in July.

- The work package for permanent installation of the inverter bus filter assembly was completed in March, and installation began with the shutdown that started in April. All work was completed by the middle of May.

- TRW provided design requirements for the modifications to the High-Voltage Room for the $1 \mathrm{~A}_{4}$ channel with $\mathrm{KCs}$ late in May, and MSE completed the design activities in June. Installation began and should be completed in time to support MHD testing in July. 


\section{Plans/Projected Activities}

MHD activities planned for the fourth quarter of FY93 include:

- reinstalling the $1 A_{4}$ channel; and

- continuing POC testing. 


\section{MINE WASTE TECHNOLOGY PILOT PROGRAM}

The objective of the Mine Waste Technology Pilot Program (MWTPP) is to provide a technology test and evaluation program through a collaborative effort among the Environmental Protection Agency (EPA); DOE; MSE, Inc.; and the Montana College of Mineral Science and Technology (Montana Tech) that:

- identifies national mine waste problems that most severely affect human health and the environment at the local, regional, and national levels;

- prioritizes the most promising mine waste treatment technologies based on their engineering and economic value;

- provides documented demonstration, test, and evaluation data on the most promising mine waste treatment technologies;

- promotes accelerated commercialization and transfer of technologies for selected mining waste treatment technologies that are developed, tested, and evaluated; and

- systematically trains users and establishes education programs.

The statement of work provided in the Interagency Agreement (IAG) identifies six activities to be completed by the MWTPP.

Activity 1-Montana Tech will establish screening criteria to identify and prioritize technical issues and promising innovative treatment techniques. Based on this criteria, a prioritized list and narrative discussion of each technical issue and treatment technique will be produced; these will then be considered as candidates for demonstration projects. Tecinnical issues of primary interest will be acid generation, mobile toxic constituents in water, mobile toxic constituents in air, cyanide, and nitrates. Wasteforms that will be reviewed relating to these issues include, but may not be limited to, pointand nonpoint-source acid mine drainage, abandoned mine acid mine drainage, streamside tailings, impounded tailings, contaminated soils, heap leach cyanide/acid tailings, sulfide-bearing mine dumps, and storm water runoff.

Activity II-Montana Tech will deliver a generic quality assurance project plan (QAPP) that will provide specific instructions on how data is to be gathered, analyzed, and reported for all activities of the MWTPP. As part of the requirements of Activity II, MSE will work with Montana Tech and incorporate DOE requirements into the generic QAPP; DOE requirements are met in MSE's Quality Management Manual. A project-specific QAPP will be developed for each demonstration under Activities III and IV.

Activity III-MSE will conduct and report on large pilot- or field-scale demonstrations of innovative technologies for remediation of mine waste. The demonstrations chosen will be the result of a thorough investigation of the technical issue, an identification of the specific wasteform to be tested, and a sound engineering and cost determination of the appropriate technology. MSE will rely on the list of technologies and wasterorms produced in Activity I; however, others may be proposed if they follow the basic criteria outlined in the IAG.

Activity IV-Montana Tech will develop and conduct bench- or small pilot-scale research of several innovative techniques that show promise for cost-effective remediation of mine waste. Projectspecific QAPPs will be written as projects are identified.

Activity $V$-MSE will be responsible for preparing and distributing all reports for the MWTPP. These include routine weekly, monthly, quarterly, and annual reports and technical progress and final 
reports for all MWTPP activities. MSE will also publicize information developed under the MWTPP in local, regional, and national publications. Any necessary public meetings and public relations will also be addressed in this activity. In addition, MSE and Montana Tech will develop and conduct a series of workshops and symposia to convey the progress and results of the MWTPP.

Activity VI-Montana Tech will develop a graduate or post-graduate degree program for environmental remediation and waste management. The program will contain elements of geophysical, hydrogeological, environmental, geochemical, mining and mineral processing, extractive metallurgical, and biological engineering. Alsn, Montana Tech will offer short courses relating to mine waste.

\section{Technical Accomplishments}

Approval was received in June from the EPA Project Officer on four additional demonstration projects under Activity III; consequently, five demonstration projects (listed below) were approved.

- Activity III, Project 1-Remote Mine Site Demonstration Project.

- Activity III, Project 2-Clay-Based Grouting Demonstration Project.

- Activity III, Project 3-Sulfate-Reducing Bacteria Demonstration Project.

- Activity III, Project 4-Nitrate Removal Demonstration Project.

- Activity III, Project 5-Biocyanide Demonstration Project.

The proposal regarding the use of low-rank coals as sorbents will be integrated into Activity III, Project 1.

Four research and development projects (listed below) to be conducted under Acti ity IV at Montana Tech were also approved.

- Activity IV, Project 1-Berkeley Pit Water Treatment Research Project.

- Activity IV, Project 2-Sludge Stabilization Research Project.

- Activity IV, Project 3-Photoassisted Reactions.

- Activity IV, Project 4-Neutral Chelating Polymers.

\section{Activity 1}

Work continued on the Science and Technology Information Retrieval System (STIRS) and Activity I, Volume 4 (nitrates). A presentation on STIRS was given May 25 at the IAG Management Committee meeting in Butte. 


\section{Activity I-Nitrates}

Work is continuing on the scoping document for Volume 4, Nitrates, at MSE.

\section{Activity III-Development Projects}

Further investigation continued on the electrochemical, wet oxidation, and biobarriers projects. Complete systems analysis, process analysis, risk assessment, and economic analysis were developed.

\section{Activity III, Demonstration Project 1-Crystal Mine Treatment}

The budget and schedule for the Crystal Mine Treatment demonstration was determined, and all equipment was received for the laboratory portion of the project, which will be conducted at Montana Tech by MSE. The final version of the agreement between the landowner(s) and MSE was completed, and the landowners are reviewing the agreement before it will be sent to DOE and EPA. Preliminary design is underway, and testing is being performed on Crystal Mine water to establish preliminary design criteria. The categorical exclusion for the laboratory activities was approved by PETC and is valid for a 5-month period. The discharge permit was received, and the conceptual design is being finalized.

\section{Activity III, Demonstration Project 2-Grouting}

An agreement with ASARCO to perform the grouting demonstration at the Mike Horse Mine site is being written. A cooperative research and development agreement prepared by the Bureau of Mines in Spokane was presented to Jon Herrmann of the EPA for concurrence; Mr. Herrmann believes the work can be conducted under the present memorandum of understanding between the U.S. Bureau of Mines and the EPA.

A confidentiality agreement is being negotiated with Morrison Knudsen to allow transfer of technical information from Morrison Knudsen to MSE regarding the STG grout.

Appendix B, which is the decision-making document for the grouting project, was completed and forwarded to the IAG Management Committee and the Technical Integration Committee. Revisions to Appendix B were advised by the EPA Project Manager. Changes will be made to that document, and the document will be redistributed.

The work plan is being developed.

\section{Activity III, Demonstration Project 3-Sulfate-Reducing Bacteria}

Technology screening was expanded in Appendix C for Project 3, and this document was completed and sent to the IAG Management Committee and the Technical Integration Committee. The work plan is currently being developed. 
Contact was made with Noranda Mining in Canada, which is demonstrating the sulfate-reducing bacteria technology at the Technology Center in Pointe-Claire (Quebec). MSE personnel will be working with Noranda personnel to determine if a team can be assembled to investigate/advance this technology.

Several possible sites for this project were visited, and the Lilly/Orphan Boy Mine was selected.

\section{Activity III, Demonstration Project 4-Electrochemical Precipitation}

The scoping document for electrochemical remediation of acid mine drainage was completed and sent to the IAG Management Committee and the Technical Integration Committee.

\section{Activity III, Demonstration Project 5-Wet Air Oxidation}

A white paper was prepared, and a scoping document is being developed.

\section{Activity III, Demonstration Project 6 - Nitrates}

The nitrates proposal is being prepared for the Montana Science and Technology Alliance (MSTA) to secure additional funding for this project. The MSTA can fund projects to $\$ 300,000$, which is the level being solicited by the MWTPP.

\section{Activity III, Demonstration Project 7-Cyanide Bioremediation}

A fully developed white paper is being prepared, and work on this project is progressing with Montana State University.

\section{Activity III, Demonstration Project 8-Coal Adsorption}

The white paper for this project is complete. This project will use information from previous work done on coal at Montana Tech.

\section{Activity IV, Montana Tech Research Project 1-Berkeley Pit}

The EPA returned nine pages of comments on the final revised QAPP, which are being incorporated. Preliminary lab work has begun.

\section{Activity IV, Montana Tech Research Project 2-Sludge Stabilization}

The work plan was approved, and preliminary work began on establishing iron and arsenic speciation in the Crystal Mine and Berkeley Pit waters. A QAPP is being prepared. 


\section{Activity IV, Montana Tech Research Projects 3 \& 4-Photoassisted Reactions and Neutral Chelating Polymers.}

Final copies of work plans for these two newly approved projects are being prepared.

\section{Activity V-Reporting, Technology Transfer, and Documentation}

The work plan is being updated.

\section{Activity VI-Education}

There are 12 applications for fellowships; five of these applicants were selected for fellowships and two were selected at graduate teaching assistant levels.

The Mine Operations and Closure Workshop drew 130 participants, including 80 people from sponsoring agencies, 25 people from the private sector, and 25 speakers. Discussions have begun with the agencies to do more workshops for them next year.

A Regression Analysis short course was held for MWTPP personnel and students.

Three video series were purchased to aid in the classroom and K-12 activities. These are Against all Odds (a statistical series), Race to Save the Planet (Mine and Mineral Waste Emphasis Program), and Earth Revealed (K-12).

\section{Major Events}

The IAG Management Committee meeting was held in Butte, Montana, on May 25-26 and included participation from the Technical Integration Committee. All activities of the MWTPP were discussed, and presentations were given regarding current projects. In addition, nine white papers were distributed regarding possible new projects; presentations were given on six of those project possibilities.

On May 27, meetings were held for the Industrial Integration Committee and the Educational Governance Committee of Activity VI; Activity VI requires Montana Tech establish a graduate and post-graduate degree program for environmental remediation and waste management.

The proposal for nitrate research made the first cut with the Montana Science and Technology Alliance, and a detailed proposal, which the board can evaluate, is being developed.

Work continues with Sandia Labs to develop a proposal for cleaning up abandoned and inactive mine sites. Other participants would be other national laboratories, the Colorado Center for Environmental Management, and the Western Governors' Association.

The first and second hydrology courses were completed. 
Initial discussions are ongoing with EPA, DOE, and the Bureau of Mines to form a team to investigate the source-control technology of grouting. Since all three agencies have been working on grouting for some time, a small demonstration project will be attempted, which would augment all activities. Discussions will continue with all three agencies to determine if a demonstration under the MWTPP can benefit all three agencies.

A meeting was held with Bill Costerton of Montana State University to discuss potential technologies for mine waste cleanup demonstrations.

A meeting was held on May 20 in Denver, Colorado, to provide a status of the MWTPP to the Western Governors' Association Mine Waste Task Force and the Colorado Center for Environmental Management. The purpose of the meeting was to bring both entities up-to-speed on the activities of the MWTPP.

Work continues with the U.S. Bureau of Mines in Spokane and in Denver regarding their participation in the MWTPP.

At the request of Mel Shupe (DOE), a technical task plan is being developed in the form of a proposal on the ultramicrobacteria technology that was presented at the last MWTPP IAG Management Committee meeting.

An outline was prepared for Mel Shupe and Jon Herrmann for the Mineral Waste Field Camp 1994. The DOE and EPA are working together to sponsor this conference.

\section{Plans/Projected Activities}

Mine Waste Technology Pilot Program activities planned for the fourth quarter of FY93 include the tasks given below.

\section{Activity 1}

Work will continue on the Science and Technology Information Retrieval System (STIRS), and Volume 4, Nitrates, will be finalized.

\section{Activity III, Project 1-Crystal Mine Treatment}

Laboratory work, permitting, and design work will continue.

\section{Activity III, Project 2-Grouting}

Site selection will be done, and on completion of site selection, the characterization phase of the project will begin and run through the quarter. Additionally, permitting requirements will be addressed. 


\section{Activity III, Project 3-Sulfate-Reducing Bacteria}

Site selection, permitting, mapping, laboratory work, and design will continue.

\section{Activity III, Project 4-Nitrates}

The site will be selected, and permitting and preliminary design work will be initiated.

\section{Activity III, Project 5-Biocyanide Remediation}

Work will continue on selecting a site, preparing the work plan, and performing preliminary design work.

\section{Activity III, Development Projects}

The Electrochemical Precipitation and Wet Oxidation projects will be investigated, and complete systems, process, and economic analyses and a risk assessment will be developed.

The development project, Biobarriers, will be presented to the DOE in an effort to obtain funding.

\section{Activity IV, Montana Tech Research Project 1-Berkeley Pit}

Preparations will be made for the project. Laboratory equipment will be centrally located, checked, and calibrated. It is anticipated the QAPP will be approved next quarter.

\section{Activity IV, Montana Tech Research Project 2-Sludge Stabilization}

Preparations will be made for the project. Laboratory equipment will be centrally located, checked, and calibrated. It is anticipated that the QAPP will be approved next quarter.

\section{Activity IV, Montana Tech Research Project 3-Photoassisted Reactions}

A final draft work plan will be prepared and submitted to the EPA for approval.

\section{Activity IV, Montana Tech Research Project 4-Neutral Chelating Polymers}

A final draft work plan will be prepared and submitted to the EPA for approval.

\section{Activity V}

The work plan will be submitted to EPA for approval. 


\section{Activity VI-Education}

Work will continue on the graduate degree program short course development for the next group of courses/workshops/seminars to be offered. A promotional flyer will be sent to approximately 10,000 people who are on the MWTPP mailing list.

A short course on groundwater contamination will be given in two sessions. 


\section{PLASMA PROJECTS}

\section{Plasma Centrifugal Furnace}

The PCF Development Program began in August 1988 with initiation of the Plasma Arc Furnace Experiment (PAFE) Project at the CDIF. The original scope of the PAFE Project was to provide a location within an EPA Superfund site to demonstrate the Retech, Inc., PCF under the EPA Superfund Innovative Technology Evaluation (SITE) Program.

In 1988, DOE contract personnel from the Idaho National Engineering Laboratory (INEL) worked with the EPA in an attempt to have the PCF demonstrated at a Superfund site on INEL property, east of Idaho Falls, Idaho. This attempt was unsuccessful; therefore, MSE personnel approached the State of Montana with the proposition that the Retech technology be demonstrated at the CDIF under the auspices of the SITE Program. The State of Montana agreed, and the project was initiated under an IAG between EPA and DOE.

The PCF was installed at the CDIF in Butte in 1989. Commissioning and startup of the PCF began with the first plasma torch ignition on October 20,1989, after which EPA and DOE Shakedown testing was performed. Results of the EPA Shakedown test series proved the applicability of the technology to totally destroy organic waste and provide a nonleachable solid product in which the waste volume is reduced by at least two-thirds. During the DOE portion of the SITE test, three Radioactive Waste Management Complex (RWMC) tests were successfully completed before the end of the fiscal year.

In 1990 , the Rocky Flats Compacted Waste Project, which used plasma technology to process simulated waste, was initiated. MSE subcontracts this work to Science Application International Corporation's Idaho office, which performs the work at Retech's Ukiah, California, facility.

In mid-summer of 1992, the INEL Buried Waste Integrated Demonstration (BWID) Program supplied funding for PCF testing. The BWID tests would attempt to establish the partitioning of a plutonium surrogate in the PCF using the RWMC-4 feed specification, which was established during the DOE

Shakedown Testing phase, but increasing the surrogate concentration to better establish its fate. One BWID test was performed in FY92.

Two Department of Defense funded projects were initiated in 1992. The first, the Pyrotechnic Ordnance Plasma Destruction (POPD) Project tested the ability of the PCF to process smoke grenades, illuminating signals, and similar pyrotechnic devices. The second project (Army II) used the PCF to destroy obsolete classified fuzes. Other incineration processes were tested for fuze destruction; however, they left recognizable components in the residue. The plasma process eliminated this problem. 


\section{Technical Accomplishments}

\section{Pyrotechnic Ordnance Plasma Destruction}

As requested by the Army/Army Armament Research, Development, and Engineering Center, MSE personnel investigated the availability and credentials for Radian Corporation and Bison Engineering to determine which company would conduct hot gas sampling. The decision was made to use Radian.

The scheduled completion of Phase II for the POPD test series was planned for May 1 in the project implementation plan; however, the anticipated completion of Phase II is now estimated to be August 2 , which is when the inal report will be delivered to the Army for final comment. A final project closeout date will be determined in early June.

\section{Army II Project}

The final report for the Army II Project was submitted for Army review on June 11.

This project is essentially complete with the remaining action being receiving comments on the final report from the Army and incorporating these comments. Comments are expected to be received on July 9 , and the final report is expected to be issued by July 20 .

\section{Testing Accomplishments}

\section{Pyrotechnic Ordnance Plasma Destruction}

Test 93-POPD-2D was completed on April 5; all ordnance was processed without significant problems.

Pyrotechnic ordnance plasma destruction tests $1,3,4$, and 5 were run during the first half of May. The scheduled completion of Phase II was planned for May 1; however, the anticipated completion is now August 1.

Tests POPD-1 and POPD-3 were completed on May 10, and test POPD-4 was completed on May 12; all ordnance was satisfactorily processed. Ground smoke signals, colored smoke hand grenades, smoke hand grenades, yellow smoke canopies, yellow smoke ground markers, booby trap simulators, artillery simulators, hand grenade simulators, projectile simulators, green smoke composition, blue dye composition, green dye composition, and orange dye composition were all successfully ir eated in these tests. 


\section{Army II Project}

The remaining MK71 MOD5 proximity fuzes were successfully processed as a part of the POPD 93-SHAKE-2 test performed on April 2.

The metals for test POPD-5 were ordered, and the test was completed on June 3-all eight of the pianned tests are now complete. Test POPD-5 processed soil spiked with a variety of metals that are typically present in pyrotechnic munitions.

\section{Operations Accomplishments}

The torch starter circuit for the PCF was moved to a separate isolated enclosure.

The muffle furnace is being wired; installation work will be done during the MHD shutdown. This project is 60 percent complete.

A replacement copper throat assembly for the PCF was procured from Retech and installed in the PCF on April 24. This replacement was returned after it developed leaks in the cooling passages, and Retech fabricated another throat assembly to a new design, and this unit is on hand at the CDIF, if required. The throat that was replaced by the new unit was repaired by an experimental procedure that involved sizing a copper plug for the hole (leak), placing solder in the gap and heating it in a furnace, then filling the remaining gap along the top with solder. The repair was inspected using dye penetrant. This throat is retained as a spare.

\section{Plans/Projected Activities}

Plasma centrifugal furnace activities planned for the fourth quarter of FY93 include:

- running the MAWS tests on the 1.5-foot PCF at Retech's facility in Ukiah, California; and

- continuing work on the Army I final report.

\section{Stationary Plasma Furnace}

The plasma hearth process (PHP), currently being tested for DOE by Science Applications International Corporation (SAIC) and Retech in Ukiah, California, through a subcontract with MSE, uses the energy generated by a plasma arc torch to pyrolize organics and to melt and vitrify inert waste components.

This technology feeds waste into a fixed crucible (unlike the rotating tub of the PCF) and uses a plasma torch to vitrify the waste material in the crucible. The project has been divided into three phases. Phase 1 is a proof-of-principle phase that will evaluate the ability of the PHP to treat several simulated waste matrices. The objective of Phase 2 is to design a fully integrated field-scale plasma treatment process; Phase 2 will consist of advanced testing on a wider range of wastes, optimization 
of the process, and completion of the design. The objective of Phase 3 will be to construct and demonstrate a prototypic field-scale plasma treatment process.

\section{Technical Accomplishments}

Field-scale process design was initiated.

The BWID test series final report is being reviewed for technical content by SAIC personnel.

The Mixed Waste Integrated Program (MWIP) test series final report was begun.

\section{Testing Accomplishments}

The test compositions for the BWID tests were determined, and testing was completed.

The MWIP test series was completed.

\section{Plans/Projected Activities}

Stationary plasma furnace activities planned for the fourth quarter of FY93 include:

- continuing the BWID FY93 report;

- issuing the MWIP final report;

- starting work on developing a new plasma hearth and associated system;

- providing technical support to DOE as required; and

- participating in the development of the Plasma Long-Range Plan. 


\section{RESOURCE RECOVERY PROJECT}

The Resource Recovery Project (RRP) was funded in August of 1992 for the purpose of evaluating, testing and demonstrating technologies for recovering water, metals, and other resources from surface and groundwater that are contaminated with dilute solutions of heavy-metals.

The primary purpose of the RRP is to determine through research, bench- and pilot-scale testing, and demonstrations, which technologies or combinations of technologies can be used by the DOE and others to recover clean, usable water from surface/underground systems contaminated with dilute solutions of heavy metals. The project will also recover valuable resources, including heavy/precious metals, as well as industrial compounds. Economic analyses of each technology and the resources recovered, will be used to project resource recovery/remediation costs for simiiar DOE and industrial sites using similar technologies. The project will focus on resource conservation and end use application of the recovered resources by maximizing resource use and minimizing nonusable byproducts.

The Berkeley Pit, an inactive open-pit copper mine, will serve as the test bed for the project.

The project has been divided into eight tasks: resource description and characterization; issue identification and analysis; technology evaluation, screening, and selection; technology demonstration and development; facility development and construction; technology transfer; project management and reporting; and formation of technical support groups.

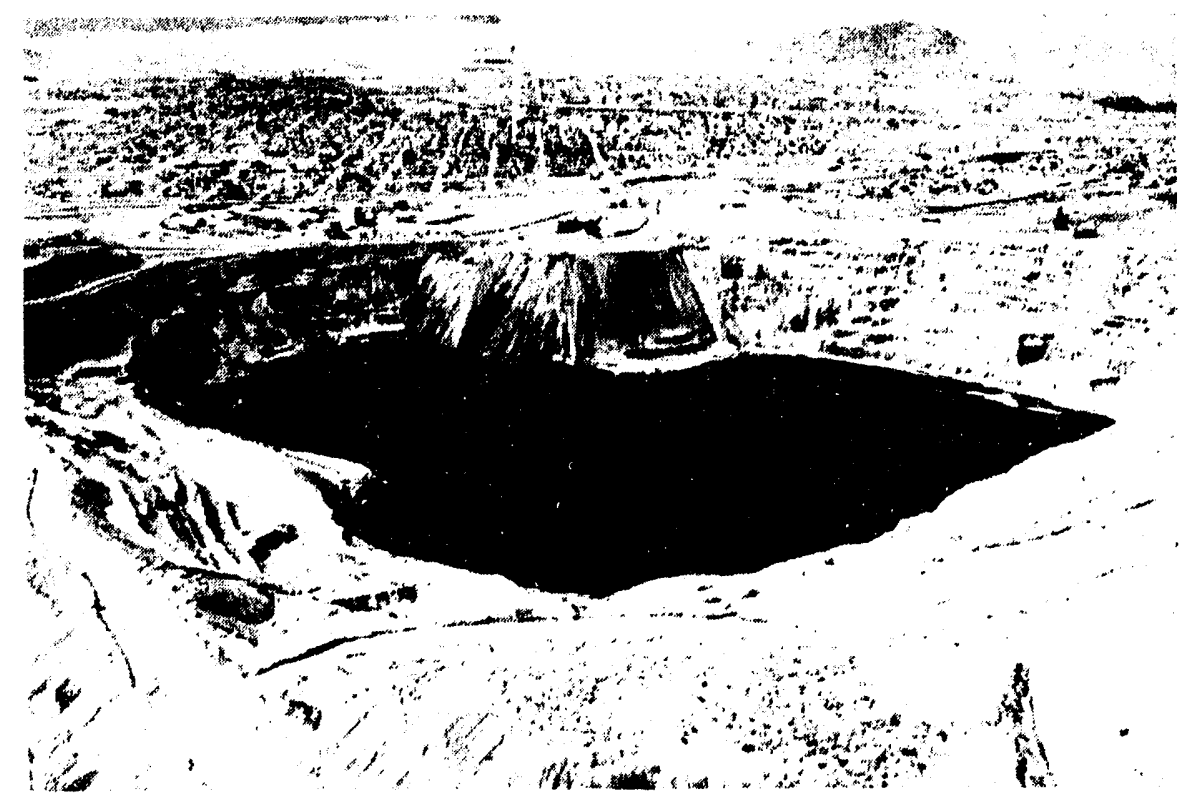

View of the Berkeley Pit, the test bed for the Resource Recovery Project.

\section{Technical Accomplishments}

The CDIF Experimental Shop will be expanded to house RRP demonstrations; the preliminary design requirements for these modifications were formalized as much as possible-many of these requirements are contingent on the flow rates that can be obtained. Legal status of the Pit water must 
be resolved before a number of preliminary design issues dealing with flow rates and storage capacity can be resolved. To proceed with the preliminary design, the storage requirements for raw Berkeley Pit water were assumed to be 10,000 gallons. The preliminary process flow diagrams are being developed, and the design work scope and analysis report were issued to the design team. MSE met with Tom Piercy of the Butte-Silver Bow Sewer Treatment Plant to discuss pretreatment discharge permits and discharge levels allowable for the CDIF. The Experimental Shop expansion will be completed March 1994.

Preliminary design work for limited testing modifications to the Experimental Shop was started; limited testing is to be performed in the first quarter of 1994.

April 30 was the cut-off date for informal proposals to be considered under the short-term screening process. The short-term screening criteria was developed, and proposals were evaluated against this criteria. Short-term technologies were then selected and concurred with by the Technical Advisory Committee.

In June, the Technology Screening Committee was formed. A draft charter for the Committee was begun, and initial contacts with some possible members were made.

Task orders were authorized with Montana Tech to support the Mineral and Mine Waste Emphasis Graduate Program, the Butte Vocational-Technical Center, the STIRS, and the Montana Tech automated catalog program.

Howard Peavey of the National Institutes for Water Resource (NIWR) met with MSE personnel and submitted a proposal to the RRP. A scope of work is being developed to request NIWR assistance in identifying water uses and water needs throughout Montana and the western states.

The confidentiality agreements are being prepared to protect proprietary rights of the technology vendors whose process will be demonstrated under the RRP.

Under Task A, Resource Description and Characterization, an analysis of water composition comparisons on Berkeley Pit versus Horseshoe Bend, and Berkeley Pit versus Kelly Mine were completed and supplied to John Mathur, DOE.

\section{Major Events}

Legal status of the Berkeley Pit water is being addressed because a significant amount of water must be transported to the CDIF to perform pilot-scale continuous tests. MSE personnel met with representatives from multiple state agencies on April 30 to discuss the legal status of the Berkeley Pit water. MSE expressed their need for large volumes of water to fulfill the goals of the project. Mr. Kirley, Montana State's superfund lawyer, is preparing a position paper on the legal status of the water, which MSE personnel expect by the end of May.

Dr. Blair Burner, WISDM, Corporation, and Norm Goldstein, Lawrence Berkeley Laboratory, acting on the part of DOE's Enterprise Task Force, conducted a 2-day seminar at MSE concerning development of a RRP Business Plan outline. An annotated outline was then presented at the RRP Enterprise meeting that was held April 22 in Phoenix, Arizona. Following the April 22 meeting, discussions were initiated with the American Alliance for Environment and Trade and the Colorado 
Center of Environmental Management concerning contractual relationships to further the RRP Business Plan.

\section{Plans/Projected Activities}

Resource Recovery Project activities planned for the fourth quarter of FY93 include:

- completing the preliminary design for the CDIF Experimental Shop expansion;

- selecting a technology for demonstration;

- finalizing the confidentiality agreement with the vendor of the technology selected for demonstration testing;

- completing approval of Project National Environmental Protection Act (NEPA) documentation, i.e., categorical exclusion; and

- completing contract preparations and the bid process for the building shell and concrete slab for the expansion of the Experimental Shop. 


\section{SODIUM SULFIDE/FERROUS SULFATE PROJECT}

The objective of the Sodium Sulfide/Ferrous Sulfate (SS/FS) Project is to determine the applicability of the SS/FS metal treatment process for point-source treatment of a number of Air Force metalbearing wastestreams. These wastestreams presently must be disposed of as a hazardous waste at considerable cost to the Air Force.

Phase I included laboratory testing to determine the chemical operating parameters for treating the wastewater generated at the Columbus Air Force Base Corrosion Control Facility. Laboratory treatment of the wastewater with the SS/FS process resulted in heavy metals removal and elevation of effluent water quality to acceptable discharge requirements.

Phase I also included designing and constructing a mobile research and development unit for testing the applicability of the SS/FS metal treatment process to a number of Air Force wastestreams.

\section{Technical Accomplishments}

The draft of the final report Skid-Mounted Sodium Sulfide/Ferrous Sulfate Metal Precipitation Project Phase I was sent to the project officer on October 26. Comments from the Air Force Civil

Engineering Service Agency (AFCESA) are expected.

The O\&M Manual will be furnished to the Air Force with the Research and Development (R\&D) unit. The as-built electrical drawings are complete.

The unit was completed; it will be stored and will have controlled access at the CDIF.

No location or funding has been identified for Phase II of the project. The MSE Project Manager and Air Force Project Officer are investigating possible contacts.

The final report was submitted for review by AFCESA; MSE time and resources will be allocated for revisions.

\section{Plans/Projected Activities}

Sodium sulfide/ferrous sulfate activities planned for the fourth quarter of FY93 include:

- continuing to supply information to the Air Force Project Officer in his search for a location to test the R\&D unit; and

- completing the final report. 


\section{SOIL W'ASHING PROJECT}

Removal of fine-grained ( $<100$ micron) radioactive contaminants from soils is an environmental restoration problem common to many DOE sites. Conventional mineral processing technologies are generally not effective in removing and concentrating small contaminant particles. However, both the patented Air-Sparged Hydrocyclone (ASH) and the patented Camphell Centrifugal Jig (CCJ) have shown promise as fine particle recovery tools.

The ASH and the CCJ may provide readily transferable heavy particle concentration technologies for remediation of plutonium and other heavy metal contaminated soils at the Nevada Test Site and other DOE facilities such as the INEL, Hanford, and Rocky Flats.

Both of these technologies are physical separation devices and process soil-water slurries. The CCJ has demonstrated success in recovering fine metal particles (<38 microns). The ASH has demonstrated effectiveness as a very rapid tine-particle flotation device and particle contractor. The ASH and CCJ are available in pilot- and production-scale models and have the ability to process several tons of soil per hour with a single unit.

The benefits afforded by these proposed soil treatment system include: 1) reduced remediation cost; 2) decreased volume of contaminants requiring disposal; and 3) availability of a developed technology.

MSE is funded by the Office of Technology Development to demonstrate, test, and evaluate these two devices. The test program was to consist of two phases-an initial phase using clean soils spiked with nonhazardous metallic surrogates for plutonium, and a second phase to be conducted at the Nevada Test Site using radioactive-contaminated soils from six participating DOE sites.

The initial test phase is being conducted in Butte, Montana, at facilities owned by Montana Tech and operated by Hydro Processing and Mining, Montana, Inc. MSE provides test direction and engineering support and analytical services.

\section{Testing Accomplishments}

Camphell Centrifugal Jig confirmation tests were completed at the Mineral Research Center, and preliminary results indicate that recoveries of bismuth in excess of 80 percent with volume reductions greater than 98 percent were obtained.

\section{Technical Accomplishments}

A laboratory at the University of Nevada-Reno will he modified to conduct physical separation demonstration tests using contaminated soils. The demonstrations will he performed with several mineral industry physical separation apparatus in addition to the ASH and CCJ. This program will be initiated during FY93 and completed in FY94. 


\section{Major Events}

No additional ASH testing is planned with HPM, Inc., because a Salt Lake City, Utah, company, Advanced Processing Technologies (APT), has obtained the license for radionuclide work with the ASH. MSE personnel are attempting to negotiate a contract with APT for completing ASH testing at their Salt Lake City laboratory. This organization has extensive experience with the ASH, and some of their staff were involved in its invention and development. A tentative start date for this testing is late July with completion in mid-August.

Contract negotiations were completed with the University of Nevada-Reno, and the revised contract was submitted to DOE-PETC for review and approval.

\section{Projected Plans/Activities}

Soil washing activities planned for the fourth quarter of FY93 include:

- completing ASH surrogate testing;

- issuing the CCJ Surrogate Test Report;

- finalizing a subcontract with the University of Nevada-Reno;

- beginning preparation of the laboratory in Reno; and

- preparing test plans for the demonstration tests to be conducted in Reno. 


\section{SPRAY CASTING PROJECT}

The objective of the Spray Casting Project is to perform research and development on the controlled aspiration process as a means of replacing electroplated chromium on United States Air Force aviation parts. The process will also he applied to near-net shape fabrication of DOE-Office of Technology Development special nuclear materials as a means of waste minimization. After the spray casting process has been Air Force qualified as a replacement for electroplated chromium, pilot-scale equipment will be designed and fabricated, and the process will be tested on aviation parts.

\section{Technical Accomplishments}

The additional fatigue bars requested by the Wright Laboratory were fabricated, spray coated with Versalloy 50, and shipped to the lab for testing. These bars were the final test specimens that were sent to the Wright Laboratory.

\section{Testing Accomplishments}

Several trial tests that atte npted to spray superalloy A286 with a boron nitride nozzle and tundish were conducted in April. These tests were not successful, and it is thought that a higher spraying temperature and compatible nozzle/tundish material will he required to successfully spray A286.

Also in April, initial spray tests for the Uranium 6 surrogate material were conducted. The surrogate material is an iron $(49.6 \%)$, tungsten $(49.6 \%)$, carbon $(0.8 \%)$ alloy that has a solid/liquid range and density similar to Uranium 6 . The initial tests were not successful because of reactions of the surrogate material with the nozzle/tundish material. In May, Uranium 6 surrogate was successfully sprayed. This successful test was conducted at a significantly higher temperature than the previous attempts.

MSE personnel experimented with using nitrogen as the system gas versus argon, which was previously used; the system operated more efficiently due to nitrogen providing better heat transfer. Nitrogen may be an excellent choice for a system gas because it provides a higher temperature capability and is one fourth the cost of argon.

Several tests were performed in which oxygen-free copper was sprayed onto various substrates. The results were very encouraging, and further testing will be performed to develop the concept.

\section{Major Events}

Project personnel are still working with the Air Force to restore funding, possibly with the help of an Air Force Logistics Center. 
Two technical papers were presented at the National Thermal Spray Conference '93 in Anaheim, California. The papers were titled Quasi-One-Dimensional Analysis of the Two-Phase Flow in a De Laval Spray Coating Nozzle and Exit Plume and Controlled Aspiration-A New Thermal Spray Process.

\section{Plans/Projected Activities}

Spray Casting Project activities planned for the fourth quarter of FY93 include:

- installing a twin-wire arc metal melting system;

- automating the pressurized tundish control system;

- completing the conceptual design for a Warner-Robbins gas heater; and

- completing procurement of the 6-axis robotic arm system. 


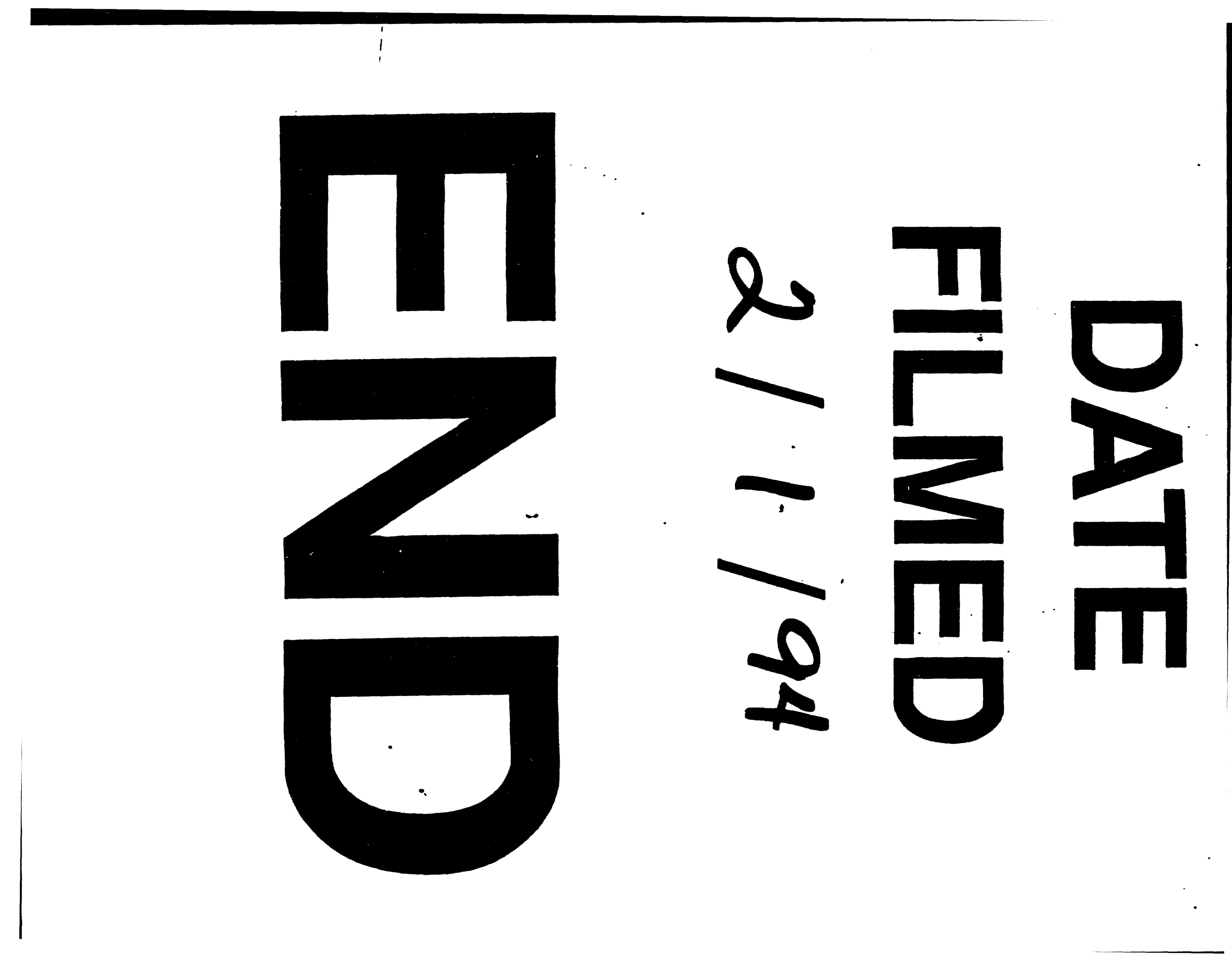


